\title{
Preparing Silk Biomaterial from Cocoon of Wild Silkmoth Attacus atlas
}

\author{
Tjokorda Sari Nindhia \\ Faculty of Veterinary Medicine Udayana University, Bali, Indonesia, 80000 \\ Email: snindhia@yahoo.com \\ Tjokorda Gde Tirta Nindhia, and I Wayan Surata \\ Mechanical Engineering, Udayana University, Jimbaran, Bali, Indonesia, 80361 \\ Email: nindhia@yahoo.com, tirta.nindhia@me.unud.ac.id, iwasura@gmail.com \\ Zdenek Knejzlik and Tomas Ruml \\ Faculty of Food and Biochemical Technology, Technicka 5, 16628, Prague Czech Republic \\ E-mail: \{zdenek.knejzlik, tomas.ruml\}@vscht.cz
}

\begin{abstract}
This Article reporting result from research in providing silk from wild silkmoth cocoon of Attacus atlas. The silkmoth is from Indonesia origin. The research was initiated by collecting the silkmoth egg from their real location. The silkmoth eggs were hatched and the larva were introduce with specific leaf that will be use as a a future food. The consideration in selecting leaf for the food is the leaf should from the three that easily and rapid grow also having ingredient that could be useful in drug, pharmacy and medical purpose. It is found the wild silkmoth Attacus atlas are like to consume a herb plant leaf of Erythrina variegate and also Cananga odorata. The cocoon resulting from feeding the caterpillar of Attacus atlas with these 2 type of leaves were observed by using scanning electron microscope (SEM) and element compositions were detected by using Energy Dispersive X-ray Spectroscopy (EDS). Different appearance of fiber are observed. With feeding with Cananga odroata resulting fiber surface covering with cubic crystal that reach with Calcium (Ca) meanwhile feeding with Erythrina variegate resulting fiber without fibrous surface which is rich with clhorine $(\mathrm{Cl})$.
\end{abstract}

Index Terms - silk, wild, cocoon, Attacus atlas, Cananga odorata, Erythrina variegate, calcium, chlorine

\section{INTRODUCTION}

Silks that is obtained from the cocoon are become long-standing interest by the scientist. The scientist put attention on appearance and behavior of cocoon produced by different type of silkworm. Recently silk have been developed as engineering fibre to make artificial composite for biomaterial in medical. To make it constructive and effective, the cocoon structure biophysics should be understood [1].

The mechanical properties of silk are impressive, with slow degradability and biocompatibility that render silk as a biomaterial for further exploration. Tissues such as bone, tendons, or ligaments are incapable of self-repair

Manuscript received February 6, 2017; revised April 20, 2017. because of the damaged or diseased. It is often required a substitute biomaterial to aid the healing process. silk fibroin protein is mechanically robust, can be designed to desired specifications, and biocompatible [2].

Silks are protein that are spun into fibers by larvae such of mites, silkworms, scorpions, spiders and flies (Lepidoptera). Silk are produced in glands through biosynthesis process in epithelial cells. The proteins are stored into the lumen of these gland prior spinning into fibers. The most characterized silks are from the domesticated silkworm, Bombyx mori, Each silks has a different composition of amino and exhibits mechanical properties to their specific functions [3]

The silkmoth Attacus atlas (Lepidoptera; Saturniidae), is an insect species that can produce silk with having value of ornamental. This moth can have maximum wing span to reach $300 \mathrm{~mm}$ and is the largest wing of all moths (Fig. 1). This species is found in china and Southeast Asia in tropical rainforest habitats at altitudes around $1500 \mathrm{~m}$. Not like domesticated mulberry silkworm of Bomyx mori that eat only one type of plant (mulberry plant), the larvae or Attacus atlas feed variety of plants They often move from one plant to another in their development [4].

The larvae of Attacus atlas produce cuticular wax from abdominal tubercles. This wax forms a white, dense, powder coating over lateral surfaces and dorsal of the larva. The function of waxes is the conservation of water, anti parasitoid, anti predator. The larvae spin silk threads to form a cocoon. The function of the cocoon is to enwrap for metamorphosis. The cocoon are composed of two proteins namely, sericin and fibroin. The functional of these protein structures includes barricade from predators, parasitoids, pathogens and assisting to complete metamorphosis by moisture and thermal. The variations in diet, and climate resulted in diversity in the type and properties of the cocoons and fibers produced by silk within the same type [5]. 
Plants derived biologically active compounds have become important source of drug. Because of the increasing recognition of herbal medicine as an alternative of health care. Erythrina variegate plants contain phyto pharmaceuticals, which have very important applications in the fields of medicine for the prevention of diseases. Medicinal plants provide molecules that lead to the discovery of new drugs. Plant metabolites that are phenolic exhibit antiallergenic, antimicrobial, antiatherogenic, antithrombotic, antiinflammatory, cardioprotective and vasodilatory effects [6].

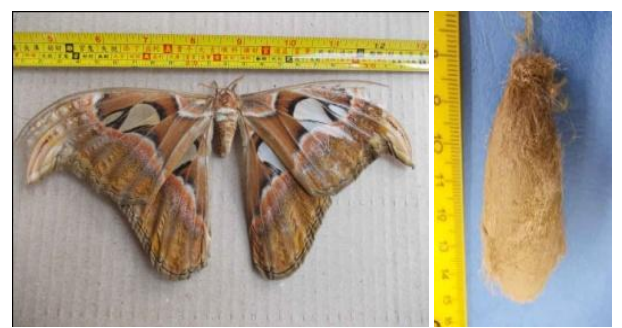

Figure 1. Silkmoth and cocoon of Attacus atlas, Indonesia origin.

Traditionally the bark of Erythrina variegate is used to treat swellings and stomachache with other herbs. Its leaves are occasionally used to treat eye ailments, to stimulate lactation and menstruation for women, to treat wind-damp obstruction syndrome in rheumatic joint pain and spasm of the limbs or lower back and knee pain. Phytochemical studies on Erythrina variegate plant have led to the isolation of many isoflavones. Isoflavones are compounds in plant foods, structurally similar to the mammalian estrogens. Recently received ttention for potential use in the prevention of postmenopausal bone loss. Data from animal experiments provided evidence that isoflavones can attenuate menopausal bone loss, and it was suggested that isoflavones is responsible for protective effects on bone [7].

It was informed that Erythrina variegate has been used in folk medicine for treatment of a narcotic and antihelminthic, tooth-ache, veneral disease, asthma, malarial fever, and insomnia. The alkaloid Erythroidine from Erythrina variegate was used as a muscle relaxant as well as Haemoerythrina alkaloids from Erythrina variegate were investigated for their anti-cancer activity [8].

Erythrina variegata is found in many tropical and subtropical regions. Phytochemical investigation of the non-alkaloidal secondary metabolites revealed the presence of one cinnamyl phenol and several isoflavonoids which exhibit activities of antibacterial and anti-inflammatory. Erythrina variegata is used medicinally as an antibacterial, antipyretic, antiinflammatory, antiseptic agent and as a collyrium [9].

Erythrina variegate having positive result as antifungal again Pythium ultimum, Rhizoctonia solani, Aspergillus fumigates, but negative for Phytophthora parasitica. It is also found that Erythrina variegate having negative result as antibacterial for Escherichia coli, Staphylococcus aureus [10].
Cananga odorata grows natively in South-East Asia, Cananga odorata is a perennial tropical tree and reported has a variety traditional uses and medicinal properties Cananga odorata oil is used to enhance euphoria during sex and also reduce sexual anxiety. The leaves of Cananga odorata is can relieve itchiness by direct topical application and also to treat dandruff [11].

It was reported that ethanolic extract of the root bark of Cananga odorata causes spermatotoxicity in male albino rats, suppresses the production of testosterone, and alters the micronutrients of the testis [12]. The bark of Cananga odorata reveal as antibacterial and antifungal activity [13].

Cananga odorata has been long utilization as fragrance component in perfumery and increase in recent year for flavoring agent in chewing gums, candies, frozen dairy, icings, candies, baked goods and soft drinks. the consumption of cananga oil from food flavoring does not pose human health effects. The Cananga odorata oils have been determined to be safe (GRAS) for food uses by the International Organisation of Flavor Industries (IOFIs) and Flavor and Extract Manufacturers Association (FEMA) and . Have been approved as food additives by US Food and Drug Administration (FDA) [14].

In this research, the leaves from Erythrina variegate and Cananga odorata plant are manage to become a food for Attacus atlas larvae. The cocoon obtained from each plant leaf will be observed and the element contain in it will be identified.

\section{EXPERIMENTAL}

The leaf of Erythrina variegate (Fig. 2) and Cananga odorata (Fig. 3) were prepared from Indonesian source. The egg of Attacus atlas were collected from their original location in Indonesia. That was provided 2 groups of larvae, one with only eat leaf of Erythrina variegate (Fig. 4) and the other group just eat leaf of Cananga odorata (Fig. 5)

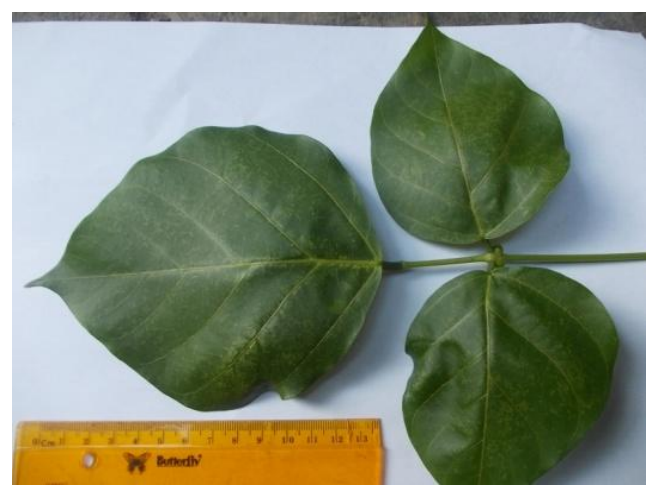

Figure 2. Leaf of Erythrina variegate.

The caterpillars of Attacus atlas were let to consume the leaves prepared and in final stage the silkworm provide themselves a cocoon for final step of metamorphose. The silkmoth of Attacus atlas was let to exit from the cocoon for the next breeding. The cocoons left by the silkmoth were collected and drying in the oven. The microstructure of the virgin cocoon were investigated 
and recorded under scanning electron microscope (SEM) with different magnification. To reveal of elements compositions in the cocoon, the Energy Dispersive X-ray spectroscopy method was introduced. The result was presented in table and graphic.

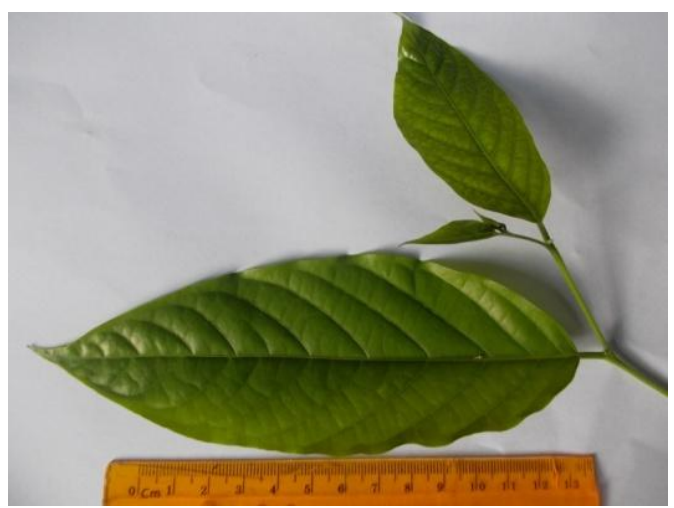

Figure 3. Leaf of Cananga odorata.

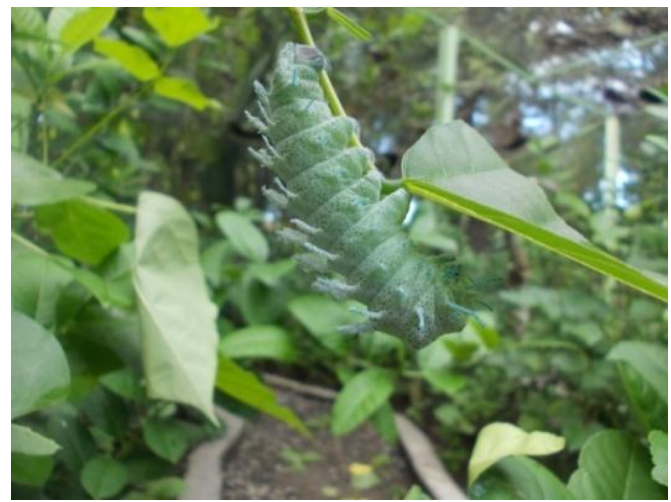

Figure 4. Carterpilar of Attacus atlas is consuming leaf of Erythrina variegate.

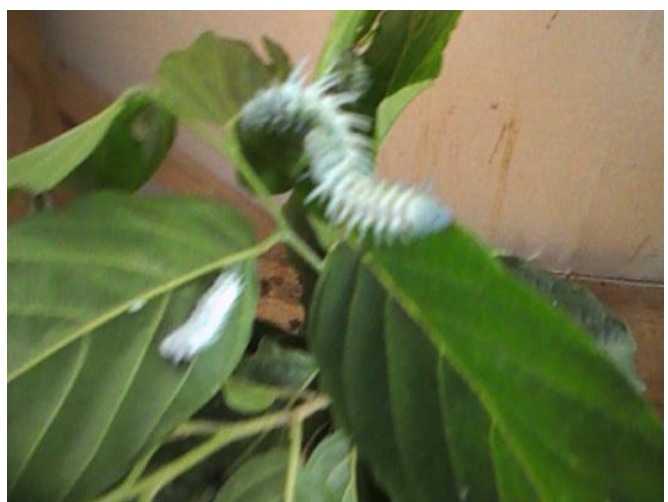

Figure 5. Caterpillars of Attacus atlas are consuming leaf of Cananga odorata.

\section{RESULT AND DISCUSSION}

The cocoon that obtained is presented in Fig. 6 for feeding with leaf of Erythrina variegate as well as in Fig. 7 for the one that feeding with Cananga odorata. The cocoons were found about in the same size and give explanation even though the silkmoths consume 2 differents 2 type of the leaves, they giving the same size of cocoon. This is also an indication that composition of the leaves of Erythrina variegate and Cananga odorata having about the same amount nutrient. This is also answering the question about why they like to consume these 2 types of leaves.

Result on observation by using SEM with low magnification $(100 x)$ can be seen at Fig. 8 for Erythrina variegate and Fig. 9 for Cananga odorata. At low magnification, the physical appearance the both cocoon is not so much different. The different between 2 type of the cocoon can be clear observed on very high magnification $(10000 x)$. Irregular crystals were found on the surface of the cocoon that was feeding with Erythrina variegate as can be seen in Fig. 10. On the other hand by feeding with Cananga odorata, the surface of the cocoon are found covering with cubic crystal as can be observed in Fig. 11.

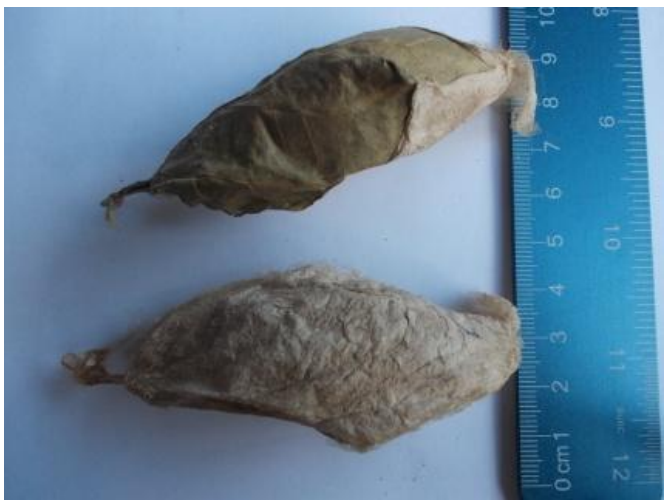

Figure 6. Cocoon of Attacus atlas yield from feeding with Erythrina variegate.

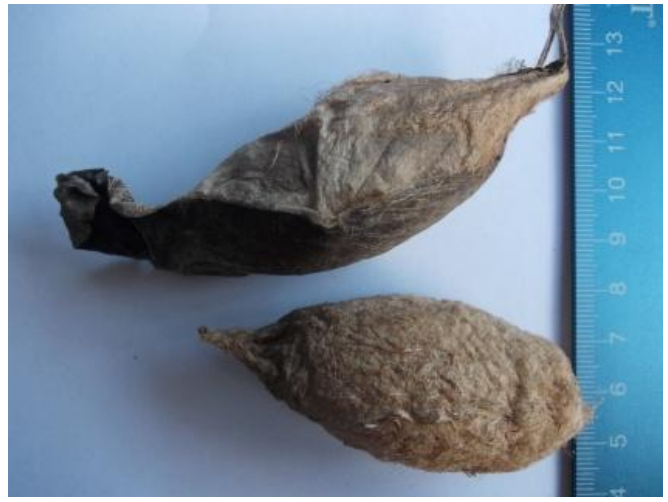

Figure 7. Cocoon of Attacus atlas yield from feeding with Cananga odorata.

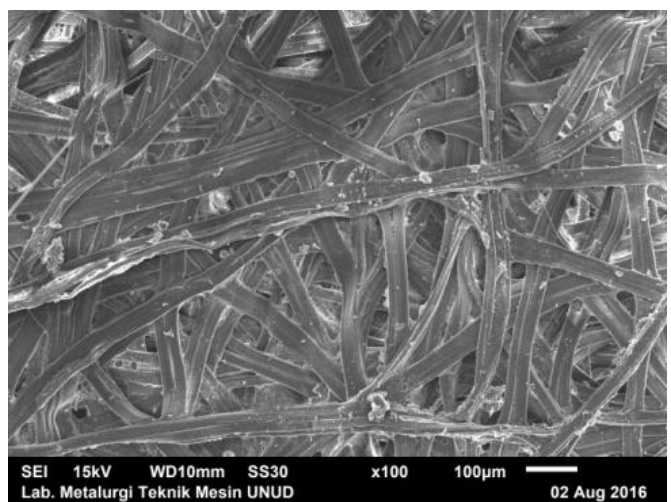

Figure 8. Cocoon of Attacus atlas yield from feeding with Erythrina variegate $(100 \mathrm{x})$ 


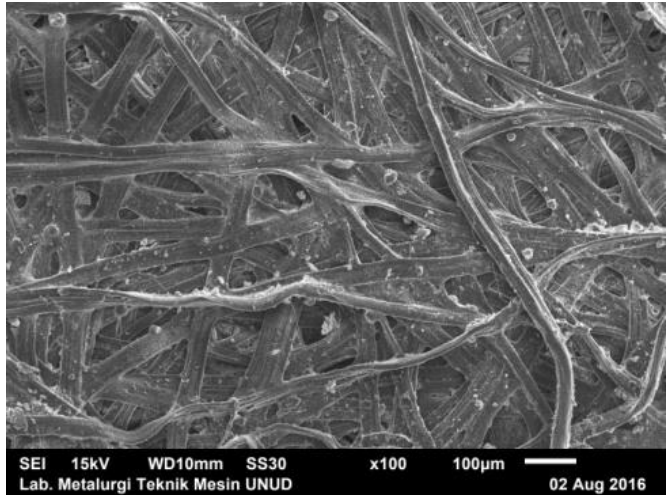

Figure 9. Cocoon of Attacus atlas yield from feeding with Cananga odorata $(100 \mathrm{x})$

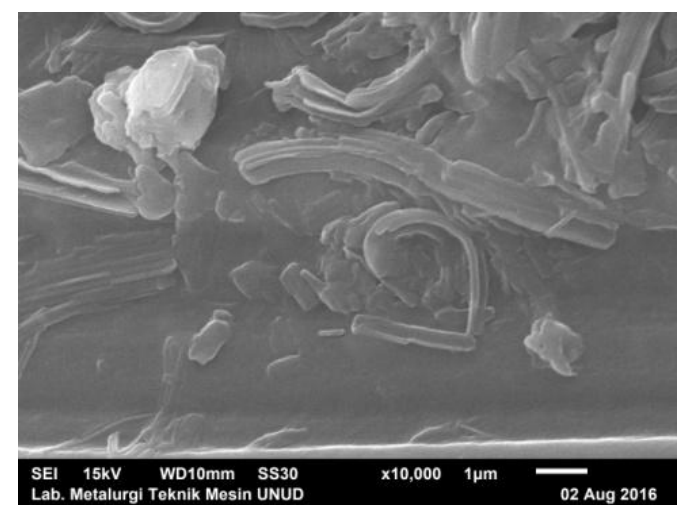

Figure 10. Irregular crystal shape were found on the surface of the cocoon feeding with Erythrina variegate (10000x).

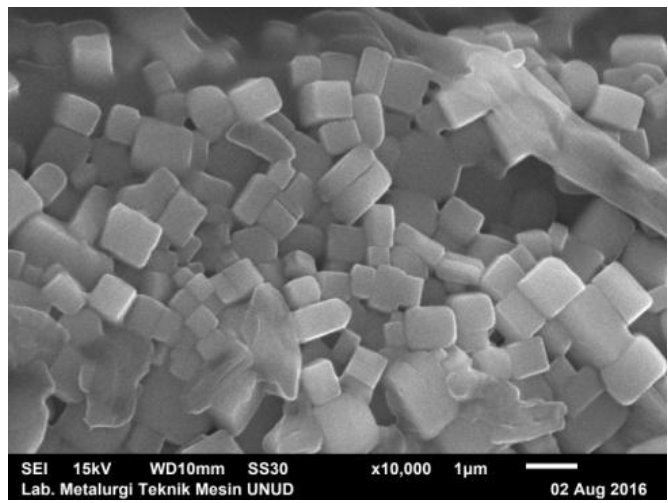

Figure 11. Cubic crystals were found on the surface of the cocoon feeding with Cananga odorata (10000x).

Elemental analysis with energy dispersive X-ray sprectroscopy (EDS) on the surface of the cocoon reveal that by feeding the larvae of Attacus atlas with Erythrina variegate resulting the cocoon contain chlorine $(\mathrm{Cl})$ around 2.96 mass\% (Fig. 12). Chlorine is not found oin the cocoon that was feeding with Cananga odorata but in reply the element of Calcium $(\mathrm{Ca})$ is present around $14.37 \mathrm{wt} \%$. The presence of calcium in the cocoon feed with Cananga odorata will give good result in biocompatibility since calcium is essential for cell physiology [12]. The other elements were found the same that are carbon $(\mathrm{C})$, oxigent $(\mathrm{O})$, and kalium $(\mathrm{K})$ as can be seen at Table I and Table II. Similar result was found for other species of wild silk that having cubic crystal on the surface such as Hyalophora gloveri , Bunaea aleinoc and Antheraea pernyi [1].

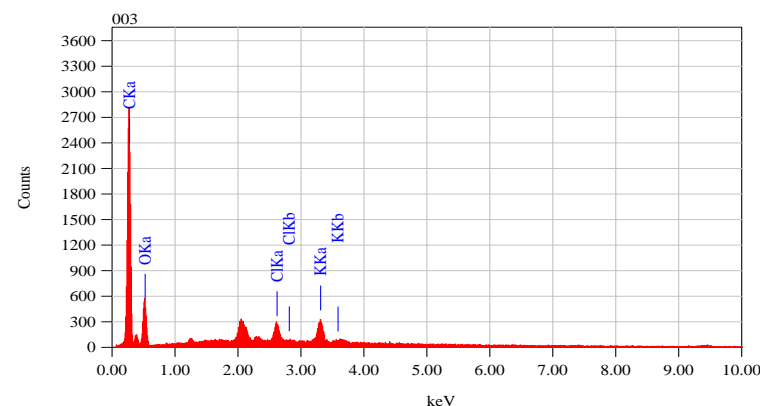

Figure 12. Energy dispersive X-ray sprectroscopy on the cocoon feeding with Erythrina variegate.

TABLE I. ELEMENTS COMPOSITION IN THE COCOON FEEDING WITH ERYTHRINA VARIEGATATE

\begin{tabular}{|c|c|c|}
\hline No & Element & Mass (\%) \\
\hline 1 & $\mathrm{C}$ & 64.86 \\
\hline 2 & $\mathrm{O}$ & 26.27 \\
\hline 3 & $\mathrm{Cl}$ & 2.96 \\
\hline 4 & $\mathrm{~K}$ & 5.92 \\
\hline
\end{tabular}

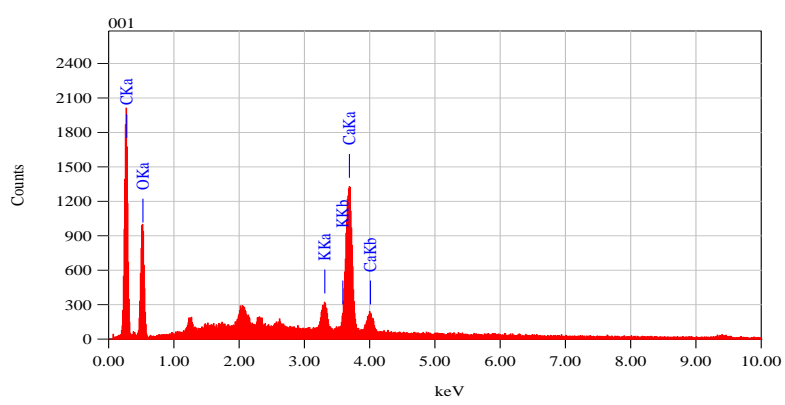

Figure 13. Energy dispersive X-ray sprectroscopy on the cocoon feeding with Cananga odorata.

TABLE II. ELEMENTS COMPOSITION IN THE COCOON FEEDING WITH CANANGA ODORATA

\begin{tabular}{|c|c|c|}
\hline No & Element & Mass (\%) \\
\hline 1 & $\mathrm{C}$ & 33.49 \\
\hline 2 & $\mathrm{O}$ & 49.49 \\
\hline 3 & $\mathrm{~K}$ & 2.29 \\
\hline 4 & $\mathrm{Ca}$ & 14.73 \\
\hline
\end{tabular}

\section{CONCLUSION}

Wild silkworm cocoon of Attacus atlas is possible for feeding with leaves of Erythrina variegate and Cananga odorata. The surface of the cocoon is covered with irregular crystal shape that is rich with chorine $(\mathrm{Cl})$. Feeding the silkworm Attacus atlas with Cananga odorata resulting cocoon that is rich with calcium $(\mathrm{Ca})$ with cubic crystal shape

\section{ACKNOWLEDGMENT}

The authors wish to acknowledge financially support from grants of the non-tax revenues (PNBP) from the scheme of international collaboration research (PNBP) of Udayana University, Bali, Indonesia with collaboration 
with the Institute Chemical Technology Prague, Czech Republic.

\section{REFERENCES}

[1] F. Chen, D. Porter, and F. Vollrath, "Morphology and structure of silkworm cocoons," Materials Science and Engineering C, vol. 32, pp. 772-778, 2012.

[2] T. G. T. Nindhia, Y. Koyoshi, A. Kanekob, H. Sawadab, M. Ohtab, S. Hiraib, and M. Uo, "Hydroxyapatite-silk functionally graded material by pulse electric current sintering," Trends Biomater. Artif. Organs., vol 22, pp 28-33, 2008.

[3] G. H. Altman, et al., "Silk-based biomaterials," Biomaterials, vol. 24, pp. 401-416, 2003.

[4] M. M. Chen, et al.,"Complete mitochondrial genome of the atlas moth, Attacus atlas (Lepidoptera: Saturniidae) and the phylogenetic relationship of Saturniidae species," Gene, vol. 545, pp. 95-101, 2014

[5] C. G. Jones, A. M. Young, T. H. Jones, and M. S. Blum, "Chemistry and possible roles of cuticular alcohols," Comp. Biochem Physiol., vol. 73B, no. 4. pp. 797- 801, 1982.

[6] S. Muthukrishnan, S. Palanisamy, S. Subramanian, S. Selvaraj, K. R. Mari, and R. Kuppulingam, "Phytochemical profile of Erythrina variegata by using high-performance liquid chromatography and gas chromatography-mass spectroscopy analyses," J. Acupunct. Meridian. Stud., vol. 9, pp. 207-212, 2016.

[7] Y. Zhang, et al., "Anti-osteoporotic effect of Erythrina variegata L. in ovariectomized rats," Journal of Ethnopharmacology, vol. 109, pp. 165-169, 2007.

[8] T. Jyothirmayi, P. G. P. Rao, and S. G. Walde, "Nitrogen extractability and functional properties of defatted Erythrina variegata flour," Food Chemistry, vol. 96, pp. 242-247, 2006.

[9] H. Tanaka, et al., "Eryvarins F and G, two 3-phenoxychromones from the roots of Erythrina variegata," Phytochemistry, vol. 62, pp. 1243-1246, 2003.

[10] E. Goun, G. Cunningham, D. Chu, C. Nguyen, and D. Miles, "Antibacterial and antifungal activity of Indonesian ethnomedical plants," Fitoterapia, vol. 76, pp. 592-596, 2003.

[11] H. Kuspradinia, A. S. Putri, E. Sukaton, and T. Mitsunaga, "Bioactivity of essential oils from leaves of Dryobalanops lanceolata, Cinnamomum burmannii, Cananga odorata, and Scorodocarpus borneensis," Agriculture and Agricultural Science Procedia, vol. 9, pp. 411-418, 2016.

[12] A. Pankajakshy and I. Madambath, "Spermatotoxic effects of Cananga odorata (Lam): A comparison with gossypol," Fertility and Sterility, vol. 91, pp. 2243-2246, May 2009.

[13] M. M. Rahman, et. al., "Antibacterial and cytotoxic compounds from the bark of Cananga odorata," Fitoterapia, vol. 76, pp. 758761, 2005.

[14] M. Kristiawan, V. Sobolik, and K. Allaf, "Isolation of Indonesian cananga oil using multi-cycle pressure drop process," Journal of Chromatography A, vol. 1192, pp. 306-318, 2008.

[15] D. Marme, Calcium and Cell Physiology, Heidelberg, Berlin: Springer-Verlag, 1985.

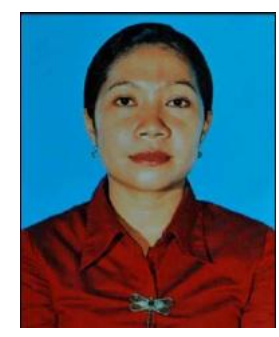

Tjokorda Sari Nindhia is Doctor in Veterinary Medicine (DVM) at faculty of Veterinary Medicine Udayana University, Bali, Indonesia since 1999. Finishing her master degree at biotechnology and biomolecular at postgraduate studies Udayana University in Bali, Indonesia

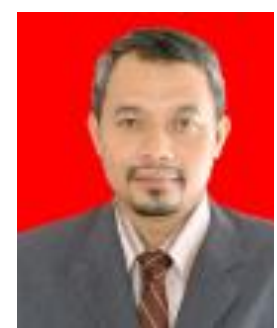

Tjokorda Gde Tirta Nindhia received Doctor Degree in Mechanical Engineering from Gadjah Mada University (UGM) Yogyakarta, Indonesia on August 2003, with major field of study was Material Engineering. His current job is as Full Professor in the field of Material Engineering at Department of Mechanical Engineering, Engineering Faculty, Udayana University, Jimbaran, Bali, Indonesia. His research interest covers subjects such as, biomaterial, waste recycle, failure analyses, ceramic, metallurgy, composite, renewable energy, and environmental friendly manufacturing.

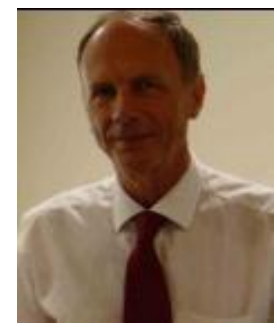

Tomas Ruml is full professor and dean of the Faculty of Food and Biochemical Technology, Technicka 5, 16628 Prague Czech Republic.

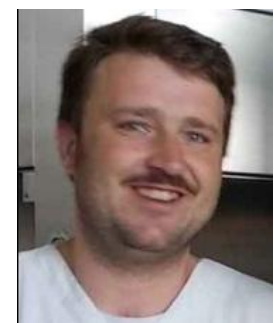

Zdenek Knejzlik. is senior researcher at Faculty of Food and Biochemical Technology, Technicka 5, 16628 Prague Czech Republic.

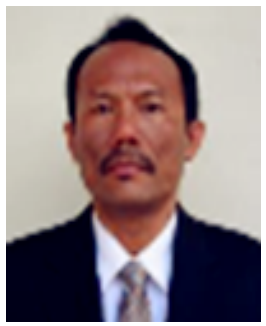

I Wayan Surata received Doctor Degree in the field of Ergonomic from Udayana University in 2011. His research interest very much related in process of manufacture. His is a full professor at Department of Mechanical Engineering, Engineering Faculty, Udayana University, Jimbaran, Bali, Indonesia. 